\title{
Assets Utilization and Performance of Manufacturing Firms in Nigeria
}

\author{
G. T. Akinleye ${ }^{1} \&$ Adesina Olufemi Dadepo $^{2}$ \\ ${ }^{1}$ Department of Accounting, Faculty of Management Sciences, Ekiti State University, Nigeria \\ ${ }^{2}$ Department of Accountancy, School of Management Studies, The Federal Polytechnic, Nigeria \\ Correspondence: Adesina Olufemi Dadepo, Department of Accountancy, School of Management Studies, The \\ Federal Polytechnic, Ile-Oluji, Ondo State, Nigeria. E-mail: olufemiadesina5@gmail.com
}

Received: November 20, 2018

doi:10.5539/ijbm.v14n4p107

\author{
Accepted: February 18, 2019 \\ Online Published: March 8, 2019 \\ URL: https://doi.org/10.5539/ijbm.v14n4p107
}

\begin{abstract}
This study examined the effect of assets utilization on performance of selected manufacturing firms in Nigeria. Secondary data were collected from the annual report and accounts of the ten selected quoted firms for a period of five years spanning from 2012 to 2016. Data collected were analyzed using descriptive statistics, correlation and regression analyses. The empirical results revealed that asset turnover(ATR) has positive and significant effect on return on assets (ROA) of the selected manufacturing firms as confirmed by the coefficient and probability value of $0.235999(\mathrm{p}=0.0000)$. Current assets ratio also has positive and significant effect on return on assets with the coefficient of $0.109040(\mathrm{p}=0.0035)$ while debt assets ratio has negative but insignificant effect on return on assets. The overall coefficient of determination $\left(\mathrm{R}^{2}\right)$ of 0.84951 showed that about $85 \%$ of the total variation in the ROA is explained by asset turnover (ATR), current ratio (CUR) and debt-assets ratio (DAR). The study concluded that assets utilization has positive and significant effect on the performance of manufacturing firms in Nigeria and therefore recommended that attention should be purposely paid to optimum asset utilization in the manufacturing firms in Nigeria.
\end{abstract}

Keywords: return on assets, manufacturing firms, asset turnover, debt assets ratio, regression analysis

\section{Introduction}

The ultimate goal of a firm is to maximize the stockholders' wealth from the financial point of view. Factors that have significant effects on determination of firm performance could be divided into micro and macro factors. Micro factors include the internal factors, whereas macro factors include the factors from external environment. Any change in the macro factors in the economy affects the firms which could be seen in the performance of the firm as well. These effects could be positive or negative depending on the change in the macro environment and structure of the firm (Demirhan \& Anwar, 2014). The study focused on micro factor and centres on the asset utilization by the manufacturing firms. A manufacturing company utilizes its assets, primarily its inventory and equipment in producing revenue. For this reason, an important financial measurement is return on assets. By dividing net income from a manufacturing plant by the assets, a manufacturing company can measure how successful its business is in utilizing its assets to develop a profit for the company.

Most organizations in Nigeria have closed down due to poor performance (Adeniyi, 2004). Up till now, organizations are failing as a result of poor performance. This poor performance may be attributed to liquidity problem, poor assets utilization and insolvency. Management problem in terms of poor assets utilization in fact, may be a significant factor resulting to the failure of some manufacturing firms. This study was carried out to empirically examine the effect of asset utilization on the performance of the selected manufacturing firms. This is the motivation for this study. Assets turnover, current assets ratio and debt assets ratios are significant variables that determine the performance of the manufacturing firms. Therefore, to gauge the appropriateness of operations and to determine how well the manufacturing process is going, a company uses the financial ratios to evaluate its business. Also, investors use these ratios as indicators to determine the performance of manufacturing companies in the area of effectiveness of assets utilization.

The objective of this study is to examine the effect of assets utilization efficiency on the performance of the selected manufacturing firms. In order to achieve the objective, the research work is structured into five parts. The first section deals with introduction, the second section reviews relevant literature on the relationship between financial ratios and the performance of manufacturing firms. Section three deals with methodology 
while section four focus on results and discussion and the last section is conclusion, implications and recommendations.

\section{Literature Review}

\subsection{Theoretical Review}

\subsubsection{Agency Theory}

This theory was propounded by Jensen and Meckling (1976), the theory emphasized that a relationship between one person (the principal) and the other (an agent) whereby the latter engage the former to perform some services on his behalf that involves delegating some decision-making authority to the agent. The said relationship should be based on trust; this is also known as fiduciary duties.

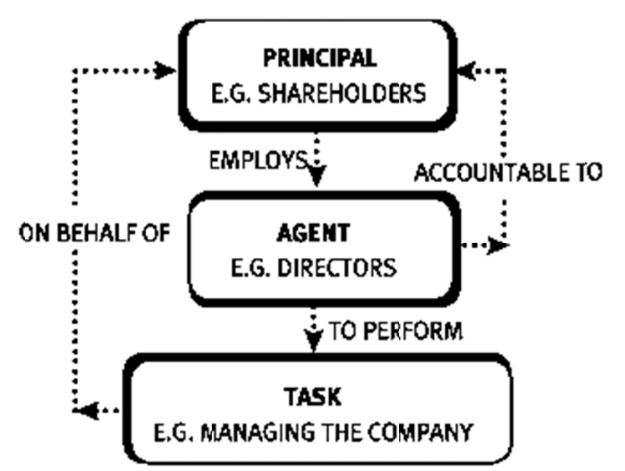

Figure 1.Relationship between the Principal and Agent

Source: Kaplan Financial Knowledge Bank (2018).

It can be deduced from fig. 2.1 that agency theory is an important theory. However, it is criticized for being a controversial theory because it raises a fundamental problem in organizations-self-interested behavior. A corporation's managers may have personal goals that compete with the owner's goal of maximization of shareholder wealth. Since the shareholders authorize managers to administer the firm's assets, a potential conflict of interest exists between the two groups. According Shehata (2014) this give rise to the problem of information asymmetry, that is, managers may have access to most of the financial information than the shareholders.

\subsubsection{Stakeholders Theory}

This theory was propounded by Freeman in 1984. Stakeholder theorists believe that taking all constituent groups into account is the better way to maximize overall firm performance. According to this theory, the intrinsic or extrinsic worth of a business is measured by a combination of financial success, usefulness to society, and satisfaction of employees, the priorities determined by the makeup of the individuals and entities that together own the shares and direct the company. Stakeholder value heavily relies on corporate social responsibility and long-term financial stability as a core business strategy. Freeman, Wicks, A.C., and Parmar, B, (2004) affirmed that stakeholder may be seen as any person or group of persons that is capable of influencing or can be influenced by the attainment of the organization's objective.

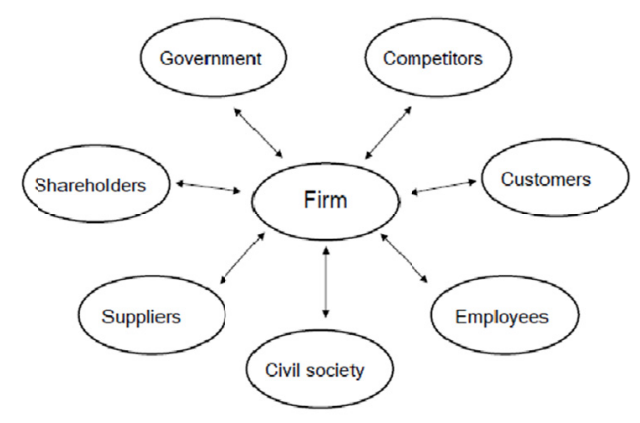

Figure 2.Stakeholderstheory model

Source: Resource gate (2019). 
This study hinges on Stakeholders' theory. The interest of all the stakeholders must be taken into consideration in the evaluation of the business performance. Organizational performance is a multi-faceted phenomenon.

\subsection{Empirical Review}

Kieu (2004) on the study of management of small business in Vietnam found out that efficiency in financial management practices such as accounting information system, financial reporting and analysis, working capital management, fixed asset management and financial planning and good performance in financial characteristics such as liquidity and business activity has a positive impact on profitability.

Issa (2012) rated 23 Iranian cement companies according to the analysis of their financial information. Grading were into 4 groups to determine the grade and position of the companies based on Ismatov's grading system: Companies with excellent management and high profitability (4.5 to 5); Companies with average management and average profitability (4 to 4.49); Companies with inefficient management and without profitability (3.5 to 3.99); Companies with poor/bankrupt and loss-making management; with a grade lower than (3.49).The study used financial ratios to determine the grade and management level of each company. The results obtained based on the analysis of their financial ratios during $2008-2010$. The study attributed the achievement of excellent result of the studied firms to the ability of managers to make profit as a result of the efficient utilization of companies' assets.

Enekwe, Okwo and Ordu (2013) examined the relationship between some financial ratios and profitability of the Nigerian Pharmaceutical industry over the past eleven (11) years period from 2001- 2011. The researcher used five (5) variables for the analyses; these are Inventory turnover ratio (ITR); Debtors' turnover ratio (DTR); Creditors' velocity (CRSV); Total assets turnover ratio (TATR) and Gross profit margin (GPM). Profitability as a dependent variable is represented by Gross profit margin (GPM). The data were analyzed using descriptive research method and multiple regressions to find out the relationship among the variables. The result of the analysis showed that there is a negative relationship between all independent variables with the profitability in the Nigerian pharmaceutical industry.

Vintila and Nenu (2015) in their study of an analysis of determinants of corporate financial performance of the sampled 46 companies listed on the Bucharest Stock Exchange in Romania within 2009-2013 periods. The selected variables were tested using multivariate regression models for unbalanced data panel. The results of the study showed that corporate performance is adversely affected by indebtedness and that financial accounting performance is positively related with company size, quantified by employees' number, but based on market approach, performance is negatively correlated with total assets.

Alo, Akosile and Ayoola (2016) examined the applicability of financial ratio analysis as tool for evaluating the performance of manufacturing industries in Nigeria, an empirical study of Guinness Nigeria Plc. (GNPLC). The findings from the computations revealed that net working capital is a good measure of the financial position of an organization over the period of time but this is not enough to get a true clear picture of the liquidity of the firm. The study advocated the application of appropriate accounting standards and other financial ratios.

None of the reviewed literature specifically focused on assets utilization and performance of manufacturing firms hence, the gap created for this study for empirical research on cross-sectional firms in Nigeria. The emphasis of this study is on asset turnover though, other variables are considered as control variables because they have the elements of assets management as reflect in their computations. The researchers are interested in asset turnover because without effective and efficient utilization of assets, other financial performances of the firm will be adversely affected.

\section{Methodology}

The population of this study consists of forty-four (44) manufacturing firms in five sub-sectors from the companies quoted on the Nigerian Stock Exchange in 2016. These sub-sectors are food products, household products, breweries, health care and Industrial (cement industry) sub-sectors. The sample size is ten manufacturing firms that were selected from these subsectors. Random sampling technique was adopted to select two firms from each of the five sub-sectors.

\subsection{Model Specification}

\subsubsection{Model Adapted}

The study adapted the model used by Lakew and Rao (2009) which expressed profitability and return on asset as functions of the efficiency of accounting reporting, efficiency of working capital, efficiency of fixed asset management, current ratio, debt ratio and total asset turnover. This is given below: 


$$
\mathrm{ROA}=\mathrm{f}(\mathrm{EARA}, \mathrm{EWCM}, \mathrm{EFAM}, \mathrm{CR}, \mathrm{DR}, \mathrm{TAT}) \ldots \ldots \ldots
$$

Where:

$\mathrm{EARA}=$ Efficiency of accounting reporting

EWCM= Efficiency of working capital management

EFAM $=$ Efficiency of Fixed asset management

$\mathrm{CR}=$ Current ratio

$\mathrm{DR}=$ Debt-ratio

$\mathrm{TAT}=$ Total asset turnover

\subsubsection{Modified Model}

However, models (1) ismodified in order to focus on assets utilization and thus:

$$
\mathrm{ROA}=\mathrm{f}(\mathrm{ATR}, \mathrm{CUR}, \mathrm{DAR}, \mu)
$$

Where: Firm performance $=$ ROA, ROE

$\mathrm{ROA}=$ Return on asset

CUR $=$ Current ratio

$\mathrm{DAR}=$ Debt-Asset ratio

$\mathrm{ATR}=$ Asset turnover

$\mu=$ Error term.

The model is therefore stated in panel data regression model as follows:

$$
R O A_{i t}=\propto_{o}+\propto_{1} A T R_{i t}+\propto_{2} C U R_{i t}+\propto_{3} D A R_{i t}+\mu
$$

Where: Firm performance $=$ ROA

$\mathrm{ROA}=$ Return on asset

$\mathrm{ATR}=$ Asset turnover

CUR $=$ Current ratio

$\mathrm{DAR}=$ Debt-Asset ratio

$\mu=$ Error term

$\alpha_{0}, \beta_{0}=$ the constant;

$\alpha_{1 \ldots} \ldots \alpha_{4}=$ the slope parameters;

$\beta_{1-----} \beta_{4}$ the slope parameters

$\mathrm{i}=$ cross-sectional variable from $1,2,3,4$.

$\mathrm{t}=$ time series variable from $1,2,3,4$

3.1.3 Measurement of Variables

Independent Variable: Assets Turnover $=$ Turnover

Total Asset

Independent (Control) Variable: Current ratio $=\underline{\text { Current assets }}$

Current Liabilities

Independent (Control) Variable: Total Liabilities to Total Assets $=\underline{\text { Total Liabilities }}$

Total Assets

Dependent Variable: $\mathrm{ROA}=\underline{\text { Profit before Interest and Taxes }}$

Total Assets

3.1.4 Methods of Data Analysis

This study used descriptive statistics, correlation and regression analyses to measure the performance of the selected manufacturing firms. Descriptive statistics was employed to determine the mean, standard deviation, minimum, and maximum value of the pooled variables for the ten selected manufacturing firms. Correlation 
analysis was considered to examine the direction and strengths of the linear relationships between the asset-turnover, current ratio, debt-asset ratio; return on asset; return on equity. Multiple regression analysis was employed for the estimation of the variables using Panel data. Panel data are cross-sectional and time-series. The observations in panel data involve at least two dimensions; a cross-sectional dimension, indicated by subscript ' $i$,' and a time series dimension, indicated by subscript ' $t$ '. The techniques of panel data estimation can take such heterogeneity explicitly into account by allowing for individual-specific variables. Finally, ratio analysis was used to measure financial performance and the strength of the selected firms.

\section{Results and Discussion}

\subsection{Ratio Analysis}

Table 1. Total Assets Turnover Ratio of the selected manufacturing firms

\begin{tabular}{lllllll}
\hline ATR & FIRMS & $\mathbf{2 0 1 2}$ & $\mathbf{2 0 1 3}$ & $\mathbf{2 0 1 4}$ & $\mathbf{2 0 1 5}$ & $\mathbf{2 0 1 6}$ \\
\hline & CadburyNig. Plc. & 0.784492 & 0.82832 & 1.058934 & 0.979174 & 1.055875 \\
& Nestle Nig. Plc & 1.311861 & 1.229897 & 1.351369 & 1.268896 & 1.072677 \\
Unilever Nig. Plc & 1.521957 & 1.371394 & 1.21904 & 1.180363 & 0.962558 \\
& P.Z Cussons Nig. plc & 1.468075 & 1.419937 & 1.410327 & 1.520082 & 1.235801 \\
& May \& Baker Nig. Plc & 0.675796 & 0.766739 & 0.848735 & 0.896008 & 0.962373 \\
& Neimeth Pharm. & 0.804196 & 0.697498 & 0.58523 & 0.663894 & 0.744521 \\
& Lafarge Cement & 0.574272 & 0.607846 & 0.308033 & 0.300463 & 0.16220 \\
Dangote Cement & 0.457748 & 0.452848 & 0.385632 & 0.34613 & 0.283601 \\
& Nigerian Breweries & 0.996217 & 1.062723 & 0.761768 & 0.823941 & 0.853398 \\
& Guinness Nig. Plc & 1.098597 & 1.011589 & 0.825236 & 0.969318 & 0.74437 \\
\hline
\end{tabular}

Source: Researchers' computation (2019).

Table 1 shows the trend of asset turnover of the selected firms. This ratio indicates the extent to which the investments in assets contribute to sales of the firms. It indicates whether the investment in assets is judicious when compared to the sales achieved by the firms. A higher ratio implies judicious asset utilization. Low ratios indicate that investment in assets is not in relation to the sales and it communicates that sales have to be pushed up.

Table 2. Current Asset Ratio of the selected manufacturing firms

\begin{tabular}{|c|c|c|c|c|c|c|}
\hline CURR & FIRMS & 2012 & 2013 & 2014 & 2015 & 2016 \\
\hline & CadburyNig. Plc. & 1.693904484 & 1.82330349 & 0.878514776 & 1.093836452 & 1.077049499 \\
\hline & Nestle Nig. Plc & 1.04672429 & 1.256452581 & 0.837611148 & 0.815556195 & 0.807513691 \\
\hline & Unilever Nig. Plc & 0.657383297 & 0.653481973 & 0.591988074 & 0.605453458 & 0.776301927 \\
\hline & P.Z Cussons Nig. plc & 2.06697725 & 2.064054758 & 1.576577906 & 1.595404317 & 1.656641337 \\
\hline & May \& Baker Nig. Plc & 1.120845875 & 1.05206605 & 1.134133283 & 1.048388658 & 1.395097301 \\
\hline & Neimeth Pharm. & 2.131164583 & 2.593667245 & 2.116878403 & 2.078413245 & 1.912412017 \\
\hline & Lafarge Cement & 0.767638443 & 0.932722082 & 0.692628054 & 0.693446154 & 0.775221601 \\
\hline & Dangote Cement & 0.851770311 & 0.906164451 & 0.572732705 & 0.800833653 & 0.496125322 \\
\hline & Nigerian Breweries & 0.654885419 & 0.451519479 & 0.496974107 & 0.408657914 & 0.51470165 \\
\hline & Guinness Nig. Plc & 0.636691986 & 0.628738357 & 0.922970505 & 0.726925422 & 0.713308071 \\
\hline
\end{tabular}

Source: Researchers' computation (2019).

Table 2 shows the trend in current ratio of the selected firms. It can be deduced from the table that almost all the firms did not meet up with the standard ratio of 2:1. In fact, some firms financed their operations by more of current liabilities than current assets as reflect in the table indicating that the firms rely so much on current liabilities. 
Table 3. Debt to Assets Ratio of the selected manufacturing firms

\begin{tabular}{lllllll}
\hline DAR & FIRMS & $\mathbf{2 0 1 2}$ & $\mathbf{2 0 1 3}$ & $\mathbf{2 0 1 4}$ & $\mathbf{2 0 1 5}$ \\
\hline CadburyNig. Plc. & 0.453074275 & 0.444209576 & 0.599514811 & 0.56767798 & 0.610581725 \\
Nestle Nig. Plc & 0.615733752 & 0.624842931 & 0.661145176 & 0.681188969 & 0.817920775 \\
& Unilever Nig. Plc & 0.724817046 & 0.779684831 & 0.836479659 & 0.840485215 & 0.838740076 \\
P.Z Cussons Nig. plc & 0.364867489 & 0.368090911 & 0.465949156 & 0.447375302 & 0.399366721 \\
& May \& Baker Nig. Plc & 0.611303233 & 0.624918961 & 0.612191756 & 0.618396595 & 0.646470097 \\
Neimeth Pharm. & 0.453921323 & 0.384240624 & 0.414039162 & 0.474001281 & 0.54535487 \\
Lafarge Cement & 0.549807094 & 0.57949241 & 0.805128493 & 0.891996509 & 0.367382303 \\
& Dangote Cement & 0.339518117 & 0.303378024 & 0.337227708 & 0.334374708 & 0.346871747 \\
Nigerian Breweries & 0.631563479 & 0.555470216 & 0.508452268 & 0.517157203 & 0.549000162 \\
Guinness Nig. Plc & 0.635773651 & 0.619702009 & 0.659470225 & 0.604558627 & 0.69589122 \\
\hline
\end{tabular}

Source: Researchers' computation (2019).

Table 3 shows the trend in debt-asset ratio of the selected firms. Some of the firms operate within the threshold of $0.50: 1$.

Table 4. Return on Asset of the selected manufacturing firms

\begin{tabular}{lllllll}
\hline ROA & FIRMS & $\mathbf{2 0 1 2}$ & $\mathbf{2 0 1 3}$ & $\mathbf{2 0 1 4}$ & $\mathbf{2 0 1 5}$ & $\mathbf{2 0 1 6}$ \\
\hline & CadburyNig. Plc. & 0.157623687 & 0.173508356 & 0.050912857 & 0.055509439 & -0.019197441 \\
& Nestle Nig. Plc & 0.302356902 & 0.260557653 & 0.280513249 & 0.286801433 & 0.250095338 \\
& Unilever NigPlc & 0.246666715 & 0.183845775 & 0.104582371 & 0.098491815 & 0.094254982 \\
& P.Z Cussons Nigplc & 0.037438278 & 0.080379642 & 0.099371039 & 0.080452539 & 0.028975331 \\
& May \& Baker NigPlc & 0.0642533 & 0.078870363 & 0.089987279 & 0.086356345 & 0.09919977 \\
Neimeth Pharm. & 0.019862263 & 0.082239883 & -0.040875289 & -0.090499549 & 0.068789354 \\
& Lafarge Cement & 0.175107645 & 0.196623545 & 0.102312877 & 0.086992384 & 0.04953688 \\
& Dangote Cement & 0.24117883 & 0.257727595 & 0.242263927 & 0.222528736 & 0.16508182 \\
& Nigerian Breweries & 0.256951065 & 0.275845578 & 0.1932019 & 0.175979034 & 0.145046585 \\
& Guinness NigPlc & 0.212024258 & 0.171942981 & 0.124260059 & 0.133981785 & 0.040883744 \\
\hline
\end{tabular}

Source: Researchers' computation (2019).

Table 4 shows the trend of return on assets of the selected firms. May \& Baker had the lowest ROA of $6 \%$ in 2012, while Nigerian breweries had the highest ROA of $27 \%$ in 2013.

The tables above pointed out the performances of individual firms in their financial ratios. These show how efficient each firm is in utilizing its assets.

\subsection{Descriptive Analysis}

Table 5. Descriptive Statistics

\begin{tabular}{llllll}
\hline Variables & Mean & Standard Deviation & Minimum & Maximum & Observation \\
\hline ATR & 0.898439 & 0.353176 & 0.162200 & 1.521957 & 50 \\
CUR & 1.076049 & 0.549852 & 0.408658 & 2.593667 & 50 \\
DAR & 0.567176 & 0.154187 & 0.303378 & 0.891997 & 50 \\
ROA & 0.135616 & 0.092782 & -0.090500 & 0.302357 & 50 \\
\hline
\end{tabular}

Source: Data analysis (2019).

Table 5 presents a summary of descriptive statistics of independent and dependent variable used in the research. It indicates the mean, standard deviation, minimum, maximum and observation. The average asset-turnover ratio of 0.898439 is equivalent of $89 \%$. This ratio is good enough and implies judicious asset utilization by the selected firms. The mean of current ratio is 1.076049 . This ratio indicates that the current assets and current liabilities are almost at par. The standard ratio should be $2: 1$. The average debt-asset ratio of 0.567176 indicates that about $57 \%$ of the assets are financed by debts. The ideal ratio is $0.5: 1$, that is, it is expected that the proportion of debt should 
not be more than $50 \%$. The average ROA of 0.135616 for the firms under study represents $13 \%$ returns on assets. Higher the ROA, better is the asset utilization in the business and vice-versa.

\subsection{Correlations Analysis}

Table 6.Correlation Matrix

Source: Data analysis (2019).

\begin{tabular}{lllll}
\hline & $\boldsymbol{R O A}$ & $\boldsymbol{C U R}$ & $\boldsymbol{D A R}$ & $\boldsymbol{A T R}$ \\
\hline ROA & 1.00000 & & & \\
CUR & -0.52676 & 1.00000 & & \\
DAR & 0.07742 & -0.44341 & 1.00000 & \\
ATR & 0.11184 & 0.13875 & 0.26676 & 1.00000 \\
\hline
\end{tabular}

The correlation matrix in table 6 reveals the relationship among the variables used in the study. As a rule, the correlation coefficients between 0 and 0.30 marks a weak correlation, from 0.30 to 0.60 a moderate correlation, and between $0.60-1.00$ a strong correlation. There is moderate negative correction of -0.52676 between ROA and current ratio. The correlation of 0.07742 between ROA and debt-asset ratio is very weak. Also, there is a weak positive correlation of 0.11184 between ROA and asset-turnover.

4.4 Regression Analysis

Table 7.Fixed Effect Estimation

Series: ROA; CUR; DAR; ATR

Dependent Variable: ROA

\begin{tabular}{|c|c|c|c|c|}
\hline Variable & Coefficient & Standard Error & T Test Values & Probability \\
\hline $\mathrm{C}$ & -0.179600 & 0.090287 & -1.989223 & 0.0541 \\
\hline ATR & 0.235999 & 0.049006 & 4.815719 & 0.0000 \\
\hline CUR & 0.109040 & 0.034966 & 3.118447 & 0.0035 \\
\hline DAR & -0.024942 & 0.086443 & -0.288537 & 0.7745 \\
\hline \multicolumn{5}{|l|}{ FIXED EFFECT } \\
\hline CADBURY & -0.419197 & 0.121756 & -3.442935 & 0.0036 \\
\hline UNILEVER & -0.115096 & 0.285929 & -0.402532 & 0.6930 \\
\hline NESTLE & 0.743320 & 0.267119 & 2.782729 & 0.0139 \\
\hline P.Z CUSSONS & -0.079192 & 0.178360 & -0.443999 & 0.6634 \\
\hline MAY \& BAKER & 0.707836 & 0.229844 & 3.079639 & 0.0076 \\
\hline NEIMETH PHARM & 0.066220 & 0.183451 & 0.360966 & 0.7232 \\
\hline LAFRAGE CEMENT & 0.080289 & 0.178878 & 3.448849 & 0.0061 \\
\hline DANGOTECEMENT & 0.821883 & 0.489526 & 3.678937 & 0.0139 \\
\hline NIGERIABREWERIES & 0.621631 & 0.377457 & 1.646892 & 0.1204 \\
\hline \multirow[t]{2}{*}{ GUINESS NIG PLC } & -0.920698 & 0.289151 & -3.184148 & 0.0062 \\
\hline & Weighted Statistics & & & \\
\hline R-Squared & 0.849531 & & & \\
\hline Adjusted R-Square & 0.800730 & & & \\
\hline F-Statistics & 17.40817 & & & \\
\hline F- Critical (Tab) & 2.610000 & & & \\
\hline Prob. (F-Stat) & 0.000000 & & & \\
\hline
\end{tabular}

Source: Data analysis (2019).

\subsection{Analysis and Discussion of Findings}

4.5.1 Assets-Turnover and Firms' Performance

The coefficients and probability values of $0.235999(\mathrm{p}=0.0000)$ for asset turnover (ATR) indicate positive and significant effect of asset turnover (ATR) on return on asset (ROA). It means, if there is a N1 naira increase in asset turnover ratio, it will translate to $24 \mathrm{k}$ in (ROA) of the studied companies. This is the most significant 
variable that has effect on the ROA as can be confirmed by its coefficient, T-test value and probability value.

\subsubsection{Current Ratio and Firms' Performance}

The coefficient and probability value of $0.109040(\mathrm{p}=0.0035)$ in table 4.6 indicate positive and significant effect of current ratio on ROA. The implication of the results is that every N1 naira increase in current ratio, it brings $11 \mathrm{k}$ in ROA.

\subsubsection{Debt- Asset Ratio and Firms' Performance}

The coefficient and probability value of $-0.02494(p=0.7745)$ in table 4.6 indicate negative and insignificant effect of debt-asset ratio (DAR) on ROA. The result implies every N1 naira increase in DAR will lead to a decrease of ROA by $2 \mathrm{k}$. The insignificance of DAR is confirmed by the probability values which are greater than $0.05 \%$ significant level.

As indicated by the regression result, the overall coefficient of determination $\left(\mathrm{R}^{2}\right)$ of 0.84951 that is, $85 \%$ of the variation in the dependent variable (ROA) is explained by current ratio, debt-asset ratio and assets turnover as explanatory variables. The F-statistics of 17.40817 which is the calculated F-statistics is greater than F-critical (tabulated) of 2.61 and the probability of F-statistics of 0.0000 is less than 0.05 percent level of significant. The implication of this is that the estimated equation can be relied upon in making valid inference about the effect of the explanatory variables on the performance of the Nigerian firms selected in the study. This result agrees with Kieu (2004) who found out that efficiency in financial management practices such as accounting information system, financial reporting and analysis, working capital management, fixed assets management have a positive impact on profitability of the organization.

\section{Policy Implication, Conclusion and Recommendations}

Information from the study on performance analysis of the selected firms will assist management of these firms to have better insights on their performance and therefore, help them to maximize the firms' value and enhancing their corporate profitability; the findings from this study will help investors understand the need for investing in the manufacturing companies with overall productivity efficient. These investors will have more confidence in the company having armed with all the facts and relevant information. Also, the results of this study will assist policy makers to implement new set of policies regarding Manufacturing sector in Nigeria to ensure continuous economic growth. Finally, it will of immense use to management accountants, academia, and students who will be interested in this study.

The study concluded that asset turnover and current ratio have positive and significant effect on the performance of the selected manufacturing firms in Nigeria and therefore, it is recommended that attention should be purposely paid to optimum asset utilization in the manufacturing firms in Nigeria. The study further recommended that financial ratios should be regularly computed and made use of by Nigerian companies in assessing their financial performance. This is because effective use of such ratios provides timely information on the financial health of the companies. Also, the management should keep ensuring that its assets are optimally utilized in order to generate more sales to the business and finally, the government should provide enabling environment such as constant electricity supply, access to raw materials and adequate security for manufacturing firms in Nigeria. These infrastructures are prerequisites for their success and promotion of economic growth.

\section{References}

Adeniyi, A. A. (2004). An Insight into management accounting, Lagos. Value Analysis Consult.

Alo, E.A., Akosile, A.I., \& Ayoola, A.O. (2016). The Statistical evaluation of the performance of financial ratio analysis in Nigerian manufacturing industry: An Empirical Study of Guinness Nig. Plc. The International Journal of Business \&Management, 4(1) 205-301.

Demirhan, H.G., \& Anwar, A. (2014). Factors affecting the financial performance of the firms during the financial crisis: Evidence from Turkey. Ege Strategic Journal, 5(1), 65-80.

Enekwe, C.I., Okwo, I.M., \& Ordu, M.M. (2013).Financial ratio analysis as a determinant of profitability in Nigeria pharmaceutical industry. International Journal of Business and Management 8(8), 107-117.

Freeman, E. R., Wicks, A.C., \& Parmar, B. (2004). Stakeholder theory and the corporate objectives revisited. Organization Science, 15(3), 364-369.

Freeman. (1984). Strategic Management: A Stakeholder Approach. New York: Cambridge University Press.

Jensen \& Meckling (1976). Theory of the firm: Managerial behavior, agency costs and ownership structure. Journal of Financial Economics, 3(4), 305-360. 
Kieu, M. N. (2004). Financial management and profitability of SME in Vetinam, DBA thesis. Southern Cross University.

Lakew, D. M., \& Rao, D. P. (2009). Effect of financial management practices and characteristics on profitability: A study on Business Enterprises in Jimma Town, Ethiopia. National Monthly Refereed Journal of Research on Commerce and Management, 2(5), 64-75.

Shehata, N. F. (2014). Theories and determinant of voluntary disclosure. Accounting and Finance Research, (3), 18-26.

Vintilă, G., \& Nenu, E.A. (2015). An Analysis of determinants of corporate financial performance: Evidence from Bucharest Stock Exchange Listed Companies. International Journal of Economics and Financial Issues, 5(3), 732-739.

\section{Copyrights}

Copyright for this article is retained by the author(s), with first publication rights granted to the journal.

This is an open-access article distributed under the terms and conditions of the Creative Commons Attribution license (http://creativecommons.org/licenses/by/4.0/). 